\title{
Waste of Felling and On-Site Production of Teak Squarewood of the Community Forest
}

\author{
Ahmad Budiaman $^{1^{*}}$, Putri Komalasari $^{2}$ \\ ${ }^{1}$ Department of Forest Management, Faculty of Forestry, Bogor Agricultural University, \\ Academic Ring Road, Campus IPB Dramaga, PO Box 168, Bogor 16680, Indonesia \\ ${ }^{2}$ Department of Forest Product, Faculty of Forestry, Bogor Agricultural University, \\ Academic Ring Road, Campus IPB Dramaga, PO Box 168, Bogor 16680, Indonesia
}

Received March 5, 2012/Accepted June 21, 2012

\begin{abstract}
Major suppliers of teak wood for the raw material of furniture industry in Indonesia are Perum Perhutani, community forests, and private forests. Community teak forest management produce roundwood or squarewood, in which squarewood is produced on the felling site by the use of chainsaw after felling and bucking activities. Utilization of teak wood from community forest has been practiced for decades, however information on the extent of utilization and the quantity of wood waste have not been published to a greater extent. The present research was intended to determine and analyze the extent of utilization and teak wood waste produced from felling and bucking, and on-site squarewood production of community forests. Quantification of wood waste from felling and bucking was based on the whole tree method, while that of squarewood production was based on the percentage of yield. It was found that the quantity of teak felling and bucking wood waste in community forest was reaching $28 \%$ offelled wood volume that consisted of branch and twig (46.15\%), upper trunk (30.77\%), short cut off (15.38\%), and stumps (7.69\%). The largest part of the wood waste of teak felling and bucking satisfied the requirement as raw material of wood working industry according to Indonesian National Standard. On-site production of squarewood increased the quantity of wood waste in the forests (in the form of slabs and sawdust).
\end{abstract}

Keywords: wood waste, felling, bucking, squarewood, community forest

*Correspondence author, email: abudiam@yahoo.co.id, telp.+62-251-8421385

\section{Introduction}

The management of teak plantation forest has given Indonesia a significant economic benefit for several decades (Tiryana et al. 2011). Teak wood has been valued as fancy wood by furniture industry along with mahogany (Irawati et al. 2009). However, information on the environmental benefit related to the management of teak plantation forest is deficient (Tiryana et al. 2011), including the information of wood waste from felling, bucking, and squarewood production processes.

Indonesia has not been able to provide the demand of teak wood for wood industry, mainly that for furniture industry. As an example, Yovi et al. (2009) reported that the future of furniture industry in Jepara has been threatened by the trend of higher raw material demand over the production capability. At national level, information of teak wood production other than that of Perum Perhutani has been insufficiently published and the production quantity has not yet been understood in detail.

Asia and Pacific countries including Indonesia were considered unable to efficiently utilizing wood raw material and leaving high quantity of highly valued waste in the forests (Enters 2001). The quantity of felling wood waste from teak plantation forest in Indonesia has not been published to a greater extent. Most of researches on felling wood waste were emphasizing wood waste from natural forest concession outside of Java and wood waste from nonteak plantation forest. The quantity of felling waste in natural forest concession, pulp-wood plantation forest, and mahogany plantation forest of Perum Perhutani were reported as much as 40\% (Budiaman 2000), 23.3\% (Budiaman \& Kartika 2004), and 16.8\% (Budiaman et al. 2005) based on the felled volume, respectively.

Currently, the management of teak forest is carried out in the forest area of Perum Perhutani, community forest, and private forest. In community and private forests, felling and bucking of wood is carried out traditionally and it is very dependent on the skill and ability of the tree feller. Furthermore, harvesting products extracted from the forests can be in the form of roundwood and squarewood. Information on the extent of utilization and the potential of wood waste from felling and bucking, and squarewood production activities are very deficient. Therefore, procurement of this information is paramount due to the fact that community and private teak forests is an alternative for the future sources of teak wood in Indonesia. The demand of teak wood has been ever increasing and teak wood has been known with its high economic value either in domestic and international markets (Mannomani \& Vanangamudi 2003; Bhat et al. 2005). 
The present research was aimed to calculate the quantity of wood waste from felling as well as bucking, and squarewood production activities in felling site of community forests. Identification of wood waste types from the above mentioned activities and calculation of roundwood assortments from felling wood waste and bucking processes based on Indonesian National Standard (INS) were carried out, as well.

\section{Methods}

The research was carried out for two months in 2009 in community forest affiliated to the Koperasi Hutan Jaya Lestari (KHJL), District of Laeya, Regency of South Konawe, Province of Southeast Sulawesi (Celebes). KHJL was established in 2004 and in 2010 has had 755 members from 32 villages in the regency of South Konawe, Southeast Sulawesi. According to KHJL (2005), 208.9 ha of forest divided into 25 management units have been managed under the program of community forest development. Each forest planter was assigned the land of $0.1-1.0$ ha. The land was planted under tumpangsari system (intercropping system). The old teak stand is consisted of mixed teak and monoculture stands planted 20-30 years ago through the program of social forestry. The average density of teak trees of diameter class above $20 \mathrm{~cm}$ was 101 tree $\mathrm{ha}^{-1}$. The topography of community forest area in KHJL is mostly flat (slope of less than 15\%) and only $20 \%$ of the area are with the slope of $25-40 \%$.

Sample trees were purposively determined and they were taken from harvesting plan endorsed by KHJL. In the present research, 30 trees inside the forest area of two cooperative members (member number of KHJL_HM_01_001 and KHJL_HM_01_02) were felled. Before fe-lling activities was carried out, the diameter at breast height (dbh) of sample trees were measured by the use of a $150 \mathrm{~cm}$ phi band. The felled trees were directly bucked and roundwood assortment with the diameter of at least $20 \mathrm{~cm}$ was converted into squarewood by the use of chainsaw. Bucking and squarewood production were done on the felling site.

In the present research, felling and bucking waste, and squarewood production waste is defined as all types of teak wood waste that are resulted from felling and bucking, and squarewood production activities of the felled trees left unutilized in the felling site by the owner of an authorized license. Quantification of felling and bucking wood waste was done based on the whole tree method.
In this method all roundwood from felling and bucking were classified into assortment of main trunk, upper trunk, branch and twig, and stump above the ground. The length and diameter of all teak roundwood assortments was measured. Measurements were carried out up to the smallest diameter $(\geq 4 \mathrm{~cm})$ and to the shortest length $(\geq 0.4 \mathrm{~m})$. The volume of the resulting assortments was then calculated and classified into utilized volume and unutilized volume (waste volume). The types of teak wood waste were subsequently grouped into assortments of small roundwood (KBK), medium roundwood (KBS), and large roundwood (KBB) (BSN 2003) as listed in Table 1. Recovery rate is the ratio between the volume of utilized roundwood and the volume of felled tree, meanwhile the waste factor is the ratio between the volume of waste and the volume of felled tree. At the squarewood production stage, the dimension of the squared wood was measured and then the volume was calculated. The volume of squarewood is the utilized volume, while the volume of slabs and sawdust is the volume of the waste. The volume of slabs was determined based on the difference between the volume of roundwood and the volume of squarewood. The yield of squarewood production is the ratio between the volume of squarewood and the volume of roundwood in percent.

\section{Results and Discussion}

Teak harvesting system in KHJL Teak harvesting stage of community forest in South Konawe consists of felling and bucking. Tree feller was people around the forest with their own personal chainsaw. Log bucking products were not skidded out of the felling field; instead it is directly processed into squarewood. In the stage of squarewood production, all sides of roundwood are trimmed with the same chainsaw used in felling and log bucking processes. Buyer determines the specification of the teak squarewood and it is classified into 3 classes, i.e. 1) $13-14 \mathrm{~cm}$ width, $\geq 110 \mathrm{~cm}$ length or $\geq$ 210 length; 2) $15-19 \mathrm{~cm}$ width, $\geq 110 \mathrm{~cm}$ length or $\geq 210 \mathrm{~cm}$ length; and 3) $\geq 20 \mathrm{~cm}$ width, $\geq 210 \mathrm{~cm}$ length. After its production, the squarewood is then skidded out of the felling site. Skidding is carried out by shouldering the squarewood and it is manually loaded into container truck parked in the side of the logging field. The squarewood is then shipped to its buyer in Java.

Waste of felling and log bucking The total volume of the 30 felled sample trees was $27.81 \mathrm{~m}^{3}$ with the average volume of

Table1 Roundwood assortments classification based on diameter and length (SNI 01-5007.1-2003)

\begin{tabular}{lcc}
\hline \multicolumn{1}{c}{ Roundwood assortment type } & Diameter $(\mathrm{cm})$ & Length $(\mathrm{m})$ \\
\hline Small roundwood $(\mathrm{KBK})$ & 4 & $\geq 2,00$ \\
& 7 & $\geq 1,00$ \\
& 10 and 13 & $\geq 0,70$ \\
& 16 and 19 & $\geq 0,40$ \\
\hline Medium roundwood $(\mathrm{KBS})$ & 22,25, and 28 & $\geq 0,40$ \\
\hline Large roundwood $(\mathrm{KBB})$ & $\geq 30$ & $\geq 0,40$ \\
\hline
\end{tabular}


tree was as much as $0.93 \mathrm{~m}^{3}$. The volume of utilized roundwood was $19.93 \mathrm{~m}^{3}$ consisted of main trunk and upper trunk. Therefore, the extent of felling product and log bucking utilization of teak in community forest of South Konawe was $77.7 \%$ with waste factor of $28.3 \%$. This indicates that for every $\mathrm{m}^{3}$ of wood felled and its $\log$ bucked, $0.72 \mathrm{~m}^{3}$ of wood were utilized and $0.28 \mathrm{~m}^{3}$ were wasted. The utilization level of wood felling and log bucking of teak in community forest of South Konawe was 2.5 time of the resulted wood waste. This finding specifies that the utilization of felling product and log bucking in community forest was reasonably good and it was not considerably different to that found in plantation forest, either in Indonesia and abroad. The wood utilization level of felling with main product of roundwood of the plantation forest in Indonesia and Finland was reported as much as $76.7 \%$ (Budiaman \& Kartika 2004) and 65-70\% (Kallio \& Leinen 2005), respectively. Furthermore, Kallio and Leinen (2005) reported that the extent of wood utilization from forest harvesting activities was dependent on harvesting system, climatic factors during harvesting, and the moisture content of the extracted wood. The extent of wood utilization in harvesting activities increased when the stump of the tree was extracted from the forest, as well (Karjalainen et al. 2004). The stumproot system is considered as an important fraction of tree biomass (Spineli et al. 2005).

Teak wood waste of felling product and log bucking is wood fractions of the teak felling product and log bucking that has not been utilized yet and left in the felling site (in the forest). The waste volume of teak wood felling and $\log$ bucking of the 30 sample trees in community forest of KHJL was $7.78 \mathrm{~m}^{3}$ consisted of stumps, short cut off, upper trunk, and branch and twig with the quantity of $0.72 \mathrm{~m}^{3}, 1.22 \mathrm{~m}^{3}, 2.49 \mathrm{~m}^{3}$ and $3.45 \mathrm{~m}^{3}$, respectively. The highest and the lowest amount of wood waste were respectively in the form of branch and twig (46.15\%) and stumps $(7.69 \%)$. The overall data of wood waste types of the teak felling product and log bucking in the community forest of South Konawe, Southeast Sulawesi are shown in Table 2.

Part of branch and twig was in the form of roundwoods with the diameter of more than $4 \mathrm{~cm}$ and at least $1 \mathrm{~m}$ in length. These roundwoods were reaching the amount of $67 \%$ and they were meeting the requirement of KBK assortment. As much as $92 \%$ of the upper trunks were also in the form of roundwood with the diameter of $16-25 \mathrm{~cm}$ and the length of $\geq 0.4 \mathrm{~m}$, in which $91 \%$ of the total upper trunk waste were meeting the requirement of KBK assortment and $9 \%$ of that was meetiing the KBS requirement. Twenty four percent of the short cut off was having the diameter of more than $12 \mathrm{~cm}$ and the length of at least $0.4 \mathrm{~m}$, in which $67 \%$ of it were meeting the requirement of KBK and the remainder was KBS assortments (Table 3). Branch and twig, upper trunk and short cut off that were not satisfying the requirement of INS roundwood assortment were mainly due to the length was shorter than that required by INS, bowing, split, fracture, and a non right angled butt (base). Overall, the quantity of KBK and KBS resulted from the wood waste of felling and log bucking of the 30 teak sample trees in South Konawe was 620 and 14 cuts, respectively. However, none of the roundwoods extracted from wood waste of felling and log bucking fulfilled the classification of KBB.

Although roundwood assortments from wood waste of teak felling and log bucking in the community forest of South Konawe is highly potential, however it has not yet been processed into a more valuable products. Currently, the utilization of wood waste from forest harvesting activities in Indonesia is a challenging endeavor due to non supporting utilization policy, low price of wood waste, and high operating cost of wood waste utilization. Any attempt to utilize harvesting waste is influenced by the capability and motivation of forest utilization entrepreneur (Nugroho \&

Table 2 Types distribution of felling and bucking wood waste of the 30 teak sample trees of Koperasi Hutan Jaya Lestari, District of South Konawe, Southeast Sulawesi

\begin{tabular}{lccc}
\hline Wood waste type & Total volume $\left(\mathrm{m}^{3}\right)$ & Average volume per tree $\left(\mathrm{m}^{3}\right)$ & Percentage $(\%)$ \\
\hline Stump & 0.72 & 0.02 & 7.69 \\
Short cut off & 1.22 & 0.04 & 15.38 \\
Upper trunk & 2.49 & 0.08 & 30.77 \\
Branch and twig & 3.45 & 0.12 & 46.15 \\
\hline Total & 7.88 & & 100 \\
\hline
\end{tabular}

Table 3 The quantity and classification of roundwood assortment extracted from felling and bucking of the 30 teak sample trees of KHJL, District of South Konawe, Southeast Sulawesi

\begin{tabular}{|c|c|c|c|c|}
\hline Waste type & $\begin{array}{l}\text { Average volume } \\
\text { per tree }\left(\mathrm{m}^{3}\right)\end{array}$ & $\begin{array}{l}\text { Do not meet with the } \\
\text { requirement of INS }(\%)\end{array}$ & $\begin{array}{l}\text { Meet the requirement } \\
\text { of INS }(\%)\end{array}$ & $\begin{array}{l}\text { Roundwood assortment } \\
\text { type }\end{array}$ \\
\hline Branch and twig & 0.12 & 33 & 67 & $\mathrm{KBK}=100 \%$ \\
\hline Upper trunk & 0.08 & 8 & 92 & $\begin{array}{l}\mathrm{KBK}=91 \% \\
\mathrm{KBS}=9 \%\end{array}$ \\
\hline Short cut off & 0.04 & 76 & 24 & $\begin{array}{l}\mathrm{KBK}=67 \% \\
\mathrm{KBS}=33 \%\end{array}$ \\
\hline
\end{tabular}


Oktorio 2004). Capability refers to technological and managerial aspects of waste utilization, and motivations closely related to incentives. Extracting wood waste from felling site is a very costly choice, since wood wastes are commonly scattered, small in size, varied in shapes and bulky (Strokes 1992). Wood wastes from forest harvesting are chipped and utilized as bioenergy in several developed countries such as Finland, England, Australia, New Zealand, and United State (Hall 2000; Hudson \& Hudson 2000; Karjalainen et al. 2004; Kallio \& Leinen 2005; Helmisaari et al. 2011). This is also done in the third world country such as Mozambique (Vasco \& Costa 2009). Wood waste processing into chips can be done in different sites and through various methods. In Sweden and New Zealand, chipping is carried out in a specifically designated processing center (Eriksson 2000; Hall 2000) by the use of stand mobile chipper (Strokes 1992). In England, wood wastes extraction system is integrated to the conventional forest harvesting system (Hudson \& Hudson 2000).

The wood waste of on-site production of squarewood Forest harvesting activities in community forest of South Konawe produce squarewood rather than roundwood as commonly found. Roundwood from log bucking was not extracted from felling site, but it was directly processed into squarewood. The total volume of log bucking from the 30 teak sample trees was $19.93 \mathrm{~m}^{3}$. Squarewoods were produced from roundwoods with the diameter of $19.5-57 \mathrm{~cm}$ and the length of $110-210 \mathrm{~cm}$. The average diameter of roundwood was $38.3 \mathrm{~cm}$. Total volume of the produced squarewood was $11.7 \mathrm{~m}^{3}$, in which the average number of squarewood produced was 5 cuts for every felled tree. The yield of on-site squarewood production using chainsaw in the community forest of South Konawe was $58.7 \%$, therefore the waste quantity of squarewood production was $41.3 \%$. This indicates that for every $\mathrm{m}^{3}$ of processed roundwood produced $0.59 \mathrm{~m}^{3}$ of squarewood and $0.41 \mathrm{~m}^{3}$ of wood wastes

The yield of on-site teak squarewood production using chainsaw in community forest of South Konawe was lower than that of authorized sawmilling, but it was higher than that of illegal sawmilling. The yield of authorized sawmilling and illegal sawmilling was $70 \%$ and $50 \%$, respectively (Purnomo 2006). Two main factors controlled the yield of squarewood production in community forest of South Konawe, i.e. order based trading system and incompatible splitting saw blade.

As has been previously mentioned, squarewood buyer determines 3 classifications of the squarewood dimension. Based on this classification, squarewood production is produced from roundwood with the diameter of over $13 \mathrm{~cm}$. Roundwood with the diameter of less than $13 \mathrm{~cm}$ will not be processed into squarewood and left in the felling site. There are 3 classes of diameter of the roundwood from felling and bucking waste according to BSN (2003), i.e. the diameter class of $4 \mathrm{~cm}, 7 \mathrm{~cm}$, and $10 \mathrm{~cm}$ that meet the requirement of roundwood assortment and can be utilized as raw material of wood working industry. However, due to the restriction of diameter determined by wood buyer is $\geq 13 \mathrm{~cm}$, all of these 3 diameter classes of roundwood are not processed into squarewood and bring about higher production of wastes. Most of the squarewood $(67.5 \%)$ were produced from roundwood with the diameter of 16-19 $\mathrm{cm}$, and the remainders were produced from these with the diameter of $10-13 \mathrm{~cm}$ and $\geq 20 \mathrm{~cm}$. Squarewood production from roundwood with the diameter of 16-19 $\mathrm{cm}$ were producing the highest amount of slabs $(25.3 \%)$. This was due to the presence of thick sapwood and less heartwood in the log. Wood buyer that mostly from small-scaled furniture industry in Java only prefers to buy squarewood with high content of heartwood. Therefore, high amount of sapwood were wasted in the production process of squarewood and it was left in the forest.

Unskilled tree feller and unsuitability of saw blade used to produce squarewood from roundwood were also important factors determining the high quantity of squarewood production waste in community forest of South Konawe, Southeast Sulawesi. In the present study, felling, log bucking, and square wood production were carried out by tree fellers that previously were illegal logger in the state owned forests in South Konawe. Felling and wood sawing skill of the fellers were simply from their experience undertook illegal logging. They have never been involved in any particular training related to saw blade, wood felling techniques, and roundwood sawing techniques to produce squarewood. Insufficient knowledge of fellers on tree felling techniques was, for instant, indicated by the height of stump left after felling. The height of stumps left after felling of trees in community forest of South Konawe was 10-54 cm with the average height of $22.4 \mathrm{~cm}$. Appropriate techniques of felling teak should result in a lower or level to the ground stumps.

Chainsaw was the main tool used to saw teak roundwood into squarewood in the community forest of South Konawe. It was the same chainsaw used in felling and log bucking. The chainsaw was designed only to carry out felling and log bucking, but not to split roundwood into squarewood. Incompatibility of operated saw blade and the absence of aiding tool to produce squarewood was resulting in wide kerfs, squarewood with irregular sides and curved, and low splitting productivity. Accordingly, the use of unsuitable saw blade produced high quantity of slabs and sawdust. Instruction and training related to felling technique, sawing technique and knowledge on proper choice of saw blade are indeed required to improve the ability and skill of the fellers. In producing on-site squarewood, a specific aiding tool that operates to control the thickness consistency of squarewood and to make straight kerfs can be coupled to the operated chainsaw. The tool should be readily handled and assembled. This aiding tool is commonly used to produce on-site sawn wood in community forest management in South American countries.

\section{Conclusion}

Important information on the extent of utilization and wood waste from felling and bucking, and on-site teak squarewood production activities using chainsaw of community forests have been gathered. It was found that wood waste produced from teak felling and bucking reached $28 \%$ and it was not reasonably different to that of plantation forests. The quantity of wood waste from on-site 
squarewood production by the use of chainsaw was $41.3 \%$ and this increased the quantity of wood wastes in community forests. Most of wood waste on site squarewood production was in the form of slabs. The quantity of roundwood fulfilled the requirement of KBK and KBS assortments from the wood wastes of felling and bucking of the community forests was reasonably high.

\section{References}

[BSN] Badan Standardisasi Nasional. 2003. SNI 015007.1.2003: Produk Kayu Bundar-Bagian 1: Kayu Bundar Jati. Jakarta: Badan Standardisasi Nasional.

Bhat KM, Nair KKN, Bhat KV, Muralidharan EM, Sharma JK. 2005. Quality timber products of teak from sustainable forest management: Proceeding of the International Conference on Quality Timber Products of Teak from Sustainable Forest Management; Peechi, India, 2-5 December 2003. Kerala Forest Research Institute. $670 \mathrm{p}$.

Budiaman A. 2000. Kuantifkasi kayu bulat kecil limbah pemanenan pada pengusahaan hutan alam. Jurnal Teknologi Hasil Hutan 8(2):36-43.

Budiaman A, Kartika EC. 2004. Kuantifkasi limbah pemanenan kayu pada pengusahaan hutan tanaman industri kayu pulp dengan metode pohon penuh di PT Inhutani II Pulau Laut, Kalimantan Selatan. Jurnal Teknologi Hasil Hutan 17(2):92-99.

Budiaman A, Gustian R, Rawenda. 2005. Limbah pemanenan di petak tebangan pada pengusahaan hutan tanaman industri di PT Inhutani II dan Perum Perhutani KPH Banten. Jurnal Teknologi Hasil Hutan 18(2):5361.

Eriksson P. 2000. Skogforsk review of system for logging residues handling in Sweden. New Zealand Journal of Forestry Science 30(1/2):88-93.

Enters T. 2001. Trash or treasure? Logging and mill residues in Asian and the Pacific. Bangkok: Food and Agriculture Organization of the United Nation, Regional Office for Asian and Pacific.

Hall P. 2000. Bioenergy fuel from stem-to-log processing waste using conventional forest harvesting system. New Zealand Journal of Forestry Science 30(1/2):108-113.

Helmisaari HS et al. 2011. Logging residue removal after thinning in Nordic boreal forests: long-term impact on the growth. Forest Ecology and Management 261:19191927. http://dx.doi.org/10.1016/j.foreco.2011.02.015
Hudson B, Hudson B. 2000. Wood fuel supply chain in the United Kingdom. New Zealand Journal of Forestry Science 30(1/2):94-107.

Irawati RH, Melati, Purnomo H. 2009. Analysis of value chain governance: scenarios to develop small-scale furniture. Journal of Tropical Forest Management 15(3):96-101.

Karjalainen T, Antti Asikainen, Jan Ilavsky, Raffaella Zamboni, Hotari KE, Röser D. 2004. Estimation of energy wood potential in Europe. Finnish Forest Research Institut. Working papers of the Finnish Forest Research Institut 6. Helsinki.

Kallio M, Leinen A. 2005. Production Technology of Forest Chips in Finland. Finland: VTT Processes.

[KHJL] Koperasi Hutan Jaya Lestari. 2005. Rencana Pengelolaan Hutan. Kendari: Koperasi Hutan Jaya Lestari.

Mannomani V, Vanangamudi K. 2003. Studies on enhancing seed determination and seedling vigour in teak. Journal of Tropical Forest Science 15(1):51-58.

Nugroho B, Oktorio R. 2004. Analisis kebijakan insentif pemanfaatan limbah pemanenan. Jurnal Teknologi Hasil Hutan 17(2):100-107.

Purnomo H. 2006. Degradasi hutan dan pengangguran: menuju pengelolaan hutan skala kecil. Journal of Tropical Forest Management 12(2): 44-46.

Strokes BJ. 1992. Harvesting small trees and forest residues. Biomass and Bioenergy 2(6):131-147. http://dx.doi.org/10.1016/0961-9534(92)90095-8.

Spineli R, Nati C, Magagnotti N. 2005. Harvesting and transport of root biomass from forest growimg poplar plantation. Silva Fennica 39(4):539-548.

Tiryana T, Tatsuhara S, Shiraishi N. 2011. Empirical models for estimating the stand biomass of teak plantation in Java, Indonesia. Journal of Forest Planning 16:177188.

Vasco M, Costa M. 2009. Quantification and use of forest biomass residues in Maputo Province, Mozambique. Biomass and Bioenergy 33:1221-1228. http://dx.doi. org/10.1016/j.biombioe.2009.05.008.

Yovi EY, Bahruni, Nurrochmat DR. 2009. Sources of timber and constrains to the timber acquisition of Jepara's small-scale furnitute industries. Journal of Tropical Forest Management 15(1):32-40. 